\title{
John Henry Newman: The Idea of a University: Book Review
}

\author{
Dongqing Han ${ }^{1}$, Jiawei $\mathrm{Wu}^{2}$,* \\ ${ }^{1}$ Jilin Normal University \\ ${ }^{2}$ Santa Monica College \\ *Correspondence Author
}

\begin{abstract}
Newman's "The Idea of the University" is the essential classic document in the history of Western higher education. All over the world, the educational thoughts of universities are closely related to Newman, and modern authors' classic understanding of the university concept is derived from this Book. At that time, academia was in an era of ideological confrontation. Debates were mainly based on the two themes of "can other schools' thoughts be used for reference" and "humanities or science." Newman gave a clear answer to this in the book and made a corresponding detailed discussion. Newman's answer embodies Newman's educational thoughts, which are formed under the guidance of personal, educational philosophy. Therefore, Newman's educational philosophy is contained in his educational thoughts. Based on this, Newman's educational philosophy is explored from the educational thoughts contained in Newman's answers to the above two topics. Newman's educational philosophy is embodied in his views on schools and disciplines. For other sects, Newman is loyal to knowledge, regardless of sect, learns from each other's strengths, and innovates. Newman firmly opposes blindly denying the views of the humanities.
\end{abstract}

Keywords: Newman, Higher education, Knowledge.

Newman mainly elaborated on the principles and goals of liberal arts education. First of all, the university is where universal knowledge is imparted, and theology is indispensable as a branch of knowledge. In addition, from the perspective of the relationship between theology and other branches of knowledge and the relationship between other branches of knowledge and theology, the necessity of retaining theology is demonstrated. Next, Newman explains the practicality of liberal arts education (liberal arts) from the perspective of students. The purpose of liberal arts education is to train the mind, expand the mind, and explain the connotation of cultivating the mind. From the perspective of professional skills, it is demonstrated that mental training is good and also helpful. Finally, from the perspective of religion, mental education makes people possess rationality and virtue, which is consistent with the part of religious education. Theology is an indispensable branch, and religion is necessary to participate in university affairs. The specific responsibility is to participate in and govern theological affairs directly. In the first chapter, he asked two questions, "In the beginning of my first discourse, as being of especial importance and interest at this time: first, whether it is consistent with the idea of University teaching to exclude Theology from a place among the sciences which it embraces; next, whether it is consistent with that idea to make the useful arts and sciences its direct and principal concern, to the neglect of those liberal studies and exercise of mind in which it has heretofore been considered mainly to consist" (p.27) In this regard, Newman used the entire book to answer the questions. For the first question, Newman believes that knowledge is not a personal point of view but that it can survive the test of time. Theological knowledge has survived 1800 years and still exists in this world, so it is a branch of knowledge. The university is a field where universal knowledge is imparted, so theology should also be retained and imparted as a branch of knowledge.
In Chapter 3, he continues to argue the rationality of retaining theology as a discipline. Theology is retained because the essence of facts can only be explored by understanding things from a holistic perspective, and the lack of a discipline neglects the completeness of cognition. Therefore, religious subjects cannot be opposed or even canceled. In the fourth chapter, In Chapter 4, Newman starts from the relationship between other branches of knowledge and theology and demonstrates the rationality of retaining theology. Each discipline has its own field. If theology is abandoned, then other disciplines will occupy the field of theology. Occupying the field of theology, the discourse of other disciplines will lack objectivity. "For example, it is a mere unwarranted assumption if the Antiquarian says, "Nothing has ever taken place but is to be found in historical documents;" or if the Philosophic Historian says, "There is nothing in Judaism different from other political institutions;" or if the Anatomist, "There is no soul beyond the brain;" or if the Political Economist, "Easy circumstances make men virtuous." These are enunciations, not of Science, but Private Judgment; and it is Private Judgment that infects every Science which it touches with a hostility to Theology, a hostility which properly attaches to no science in itself whatever" (p.87).

The fifth to eighth chapters discuss the value of liberal arts education. First, he systematically explained the connotation of liberal arts education. University education should carry out liberal arts education. The core of liberal arts education is to train the mind by learning common knowledge and pursuing excellence. "Liberal Education, viewed in itself, is simply the cultivation of the intellect, as such, and its object is nothing more or less than intellectual excellence" (p.107). Moreover, students respect each other, discuss each other, and learn from each other. In the course of communication and learning, ideas are inspired, and the connections between the various parts are clearly and objectively understood. The connections between the various parts are conducive to 
grasping the essence of things as a whole. Then Newman will explain the value of liberal arts education. The value of liberal arts education philosophy lies in learning general knowledge. Because knowledge itself is valuable and a kind of wealth, the liberal arts education of learning knowledge also has. Furthermore, liberal arts education can also train people's minds, enable them to think critically and evaluate things objectively and rationally. Finally, liberal arts education can also cultivate people's morality to some extent. This kind of morality is self-confidence, humbleness, friendliness, temperance, calmness, hard work, thrift, and all other good qualities. "Such are some of the lineaments of the ethical character, which the cultivated intellect will form, apart from religious principle" (p.175).

The last chapter proposes that theology as a branch of general knowledge should be entered into school because knowledge can complement and correct each other. "Let her do for Literature in one way what she does for science in another, each has its imperfection, and she has her remedy for each" (p.193). The church should directly manage theological affairs. Furthermore, specialized departments should be responsible for specialized affairs.

In addition, Newman also has some lectures and essays on topics related to university subjects. He believes that Christianity and classical literature can expand the mind and show noble and graceful behavior. Therefore, they should be kept in a proper position. Catholic literature, religious literature, and natural Science are irreplaceable. Theology and natural sciences have their suitable research methods for the problems they are exploring. Whether it is induction or deduction, they are all part of the truth. There should be no prejudice to look at the research methods suitable for each other or deny this discipline. When there are differences between the two in the comparison process, use a more tolerant, peaceful, and calm attitude to judge the different conflicts. Therefore, as I have already been making overtures of reconciliation, first between Polite Literature and Religion, and next between Physics and Theology, so I would now say a word by way of deprecating and protesting against the needless antagonism, which sometimes exists in fact, between divines and the cultivators of the Sciences generally (p.265).

Regarding faction disputes, Newman, who is in an era of ideological confrontation, believes that people should not deny his ideas or terminate cooperation for people who are on the opposite side of people's thoughts. It is knowledge-oriented and learns from each other's strengths. Newman was exposed to studying Christian literature, and he understood the principles of Catholicism and the ideas of Protestantism. The clash of ideas from these different factions, Newman's witnesses in that era, have already understood them deeply, sincerely, and prudently inferring theories to prove the ideas of all factions, advocating knowledge, regardless of faction, learning from each other's strengths, innovation, and innovation have become the methodology of his ideological system.
Newman believes that knowledge is closely intertwined in response to disciplinary bias, so we cannot separate one part from another. Each discipline involves mental and abstract knowledge and is a logical argument for one aspect of the entire research object. Their respective concepts are logical and accurate to their respective goals, but they are in between themselves and things the relationship between them is incomplete. Therefore, each discipline needs to calibrate, adjust and evaluate each other. For this reason, ignoring any discipline will affect the precise and complete understanding of knowledge.

Classic works are still valuable after the polishing of time. In the book "The Idea of the University," Newman's educational thoughts still have theoretical guiding significance for researchers and practitioners in universities today. Today, educators and researchers often use Newman's theory when criticizing neoliberalism and privatization in higher education. They advocate a more comprehensive view of contemporary universities (Blass, 2001; Craig et al., 1999; Deboick, 2010; Thornton, 2004). Teachers who are interested in "Whole person" education, including critical thinking skills and aesthetic appreciation, regularly quote Newman's conceptualization of "liberal education" (Christie, 2011; Gruenwald, 2011; McAllister, 2015; Sullivan, 2015).

\section{References}

[1] Blass, E. "What's in a Name? A Comparative Study of the Traditional Public University and the Corporate University", Human Resource Development International, 4.2 (2001): 153-172.

[2] Cornwell, J. Newman's Unquiet Grave: The Reluctant Saint. New York: Continuum, 2010. Craig, R. J., Clarke, F. L., \& Amernic, J. H. "Scholarship in University Business Schools-Cardinal Newman, Creeping Corporatism, and Farewell to "Disturber of the Peace?", Accounting, Auditing, and Accountability Journal, 12.5 (1999): 510-524.

[3] Deboick, S. "Newman suggests a university's 'soul' lies in the mark it leaves on students," The Guardian, 2010. Dunne, J. 'Newman Now: Re-examining the Concepts of "Philosophical" and "Liberal" in "The Idea of a University," British Journal of Educational Studies, 54.4 (2006): 412-428.

[4] Thornton, M. "The Idea of the University and the Contemporary Legal Academy," Sydney Law Review, 26 (2004): 1-22.

[5] Christie, R. C. "Newman's Aesthetic Vision: Theology and the Education of the Whole Person," Journal of Interdisciplinary Studies, 23.1/2 (2011): 43-57.

[6] Gruenwald, O. "The University as Quest for Truth," Journal of Interdisciplinary Studies, 23.1/2 (2011): 1-18.

[7] McAllister, J. "The Idea of a University and School Partnership," in R. Heilbronn \& L. Foreman-Peck, eds, Philosophical Perspectives on Teacher Education. Chichester: Wiley, 2015. 38-53.

[8] Sullivan, J. "Newman's Circle of Knowledge and Curriculum Wholeness in "The Idea of a University", in F. D. Aquino \& B. J. King, eds, Receptions of Newman. Oxford: Oxford University Press, 2015. 95-113. 